\title{
Estimation of Waste Generation from Tidal Flood in North Semarang Sub-District
}

\author{
All Denicko Roynaldi1, ${ }^{1,}$, Maryono Maryono \\ ${ }^{1}$ Department of Urban and Regional Planning, Faculty of Engineering, Diponegoro University, 50275 Semarang - Indonesia
}

\begin{abstract}
Tidal floods often occur in North Semarang Sub-District due to rising sea levels. One of the impacts is waste generation. Waste management is needed to prevent environmental degradation. An important factor is quantity of waste for the management plan. The purpose of this study to estimate waste generation from tidal floods. Scenario models are needed to find out the area affected because there is no existing data. Scenario data uses DEMNAS, land subsidence data, tidal data, and Sea Level Rise data. The Admiralty method is used to determine the Highest High Water Level (HHWL) value, the quantitative spatial method for the tidal flood scenario and the estimated quantity of waste. Calculation of the HHWL value of $1.16 \mathrm{~m}$ is added to the SLR data. The result of tidal flood height is $1.27 \mathrm{~m}$. There are three affected villages (Panggung Lor, Bandarharjo, and Tanjungmas) and affected area is $55.95 \mathrm{Ha}$. The accuracy rate is $82.86 \%$ which is tested using Confusion Matrix. The results of the scenario model are arranged in a grid and then sampled. The estimated waste yield is $70,095.26 \mathrm{~kg}$. The benefits of this data are to facilitate cleaning agent in waste management including cost and technical planning.
\end{abstract}

Keywords: tides; sea levels rise; tidal floods; disaster waste generation

\section{Introduction}

Global warming is a serious problem that can increase the volume of global seawater and can encourage sea level rise (sea level rise) by $0.5-2.3 \mathrm{~m}$ at the end of this century [1]. The consequence is that sea levels will increase in the future if they coincide with the phenomenon of land subsidence. Sea level rise can cause coastal areas to be vulnerable to inundation by tidal flooding and can result in environmental degradation [2,3]. Tidal floods can occur due to conditions of land elevation that are lower than sea level at high tide.

The tidal flood has indeed become one of the serious challenges globally including the Asia Pacific region such as Indonesia. Given that Indonesia is a maritime country ranked fourth globally with the most inhabitants living in coastal areas [4]. The research mentioned that the Indonesian population is around $20 \%$ or \pm 41.61 million people who live in coastal areas with low elevation or Low Elevation Coastal Zone (LECZ).

The National Survey and Mapping Coordinating Board/ Badan Koordinasi Survei dan Pemetaan Nasional (Bakosurtanal) through the explanation of the Semarang City Regulation Number 13 of 2010 concerning the Implementation of Disaster Management in the City of Semarang has mapped the area that has the potential for tidal flooding. The document states that the coast of Java, including the northern part of Semarang City, has one of the most potential flooding areas, one of which is the North Semarang Sub-District. Bappeda in Semarang City states that the height of this region is around \pm 0.75 meters above sea level and is very prone to tidal disasters. In 2016, tidal flood modeling obtained the extent of tidal flood submission through scenarios reaching $78.8 \%$ of the total area [5]. The phenomenon of tidal flood is caused by tides caused by the attraction of the earth to the celestial bodies which cause seawater on the surface to move dynamically and differently in each region [6]. The moon's attraction to the earth is the greatest influence compared to the attraction between the sun and the earth because the distance of the moon to the earth is closer than the distance from the sun [7]. Tides are interpreted as a natural phenomenon that occurs due to rising and falling sea levels [8].

The phenomenon of land subsidence in the northern part of Semarang City every year is also one of the factors causing tidal floods. Land subsidence in North Semarang reaches $10 \mathrm{~cm}$ per year [5]. Other factors such as tidal values on the coast of North Semarang. Scenario models are needed to find out the area affected because there is no existing data. Tidal flood can occur at any time even when there is no rain, tidal flood can soak the coast of North Semarang Sub-District. Tidal floods can have a serious impact on the environment. Among the environmental impacts caused by the tidal flood disaster, waste generation is one of the impacts that occur. This is problem that must be dealt with effectively and efficiently as well as data collection on the quantity of waste is one of the important factors in handling waste due to disaster [9]. Losses due to natural disasters are not only determined by actions taken after disasters but also by

\footnotetext{
* Corresponding author: alldenickoroynaldi@gmail.com
} 
disaster prevention actions are taken before disaster events $[10,11]$.

In the same context, flooding due to high rainfall can also produce waste generation and differentiate the cause of inundation. A study in Kawasaki City, Japan, which estimated waste generation from flooded found an estimated 229,000 tons of waste [12]. Waste generation due to flooding in Thailand in 2011 caused an estimated waste of 3.25 million tons [13]. In Indonesia, the estimation of waste generation due to floods is rarely done. However, a study has been conducted to estimate waste generation due to other disasters such as the tsunami disaster. In the aftermath of the 2004 Aceh Tsunami, which was examined by UNEP (United Nations Environment Program) in 2008, it estimated that waste generation reached 4,700,000 tons. A study after tsunami in Mentawai in 2010, it was estimated that waste generation reached 250,000 tons [9].

The Media of CNN Indonesia in May 2018 the DKI Jakarta Environment Agency transported about 50 tons of waste due to tidal flood on the Muara Angke coast to Bantar Gebang, Bekasi [14]. This means that the phenomenon of tidal flooding also has potential for waste generation. The impact of the tidal flood phenomenon in the North Semarang Sub-District of the coast has similarities as in the Muara Angke coast, one of which is the generation of waste. However, in this region there has not been a study of estimation of the quantity so that it becomes an obstacle for the authorities in cleaning it.

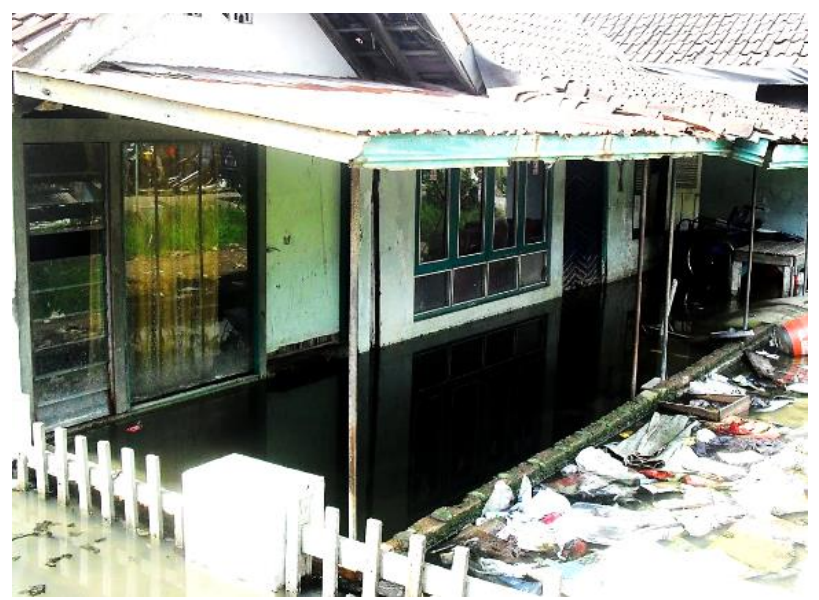

Fig. 1. Waste generation affected tidal flood in Tanjugmas, North Semarang Sub-District

(Source: Rahmat P/ http://portalsemarang.com/robbandarharjo-antara-realitas-dan-solusi/)

The emergence of waste due to disasters (disaster waste), both solid and liquid waste is a threat to health, safety, and the environment, and can also be a major barrier to post-disaster action [15]. One important factor in disaster prevention, which is an understanding of the amount and characteristics of disaster waste [16]. But the fact is there is no estimation of the quantity of waste due to tidal data in North Semarang Sub-District. Therefore, this becomes important to do a study of estimation of waste generation due to tidal flood based on the scenario. It is hoped that this can be an input for the Semarang City Government, especially the Sanitation and Parks
Department so that it can plan the management of the tidal flood disaster in the North Semarang Sub-District which is right on target so that it will create environmental cleanliness and reduce environmental pollution due to tidal flooded waste.

\section{Data and methodology}

The data used in this study were sourced from primary and secondary data. Primary data include image interpretation, interviews, and field observations including waste weight sampling. Secondary data is done in the form of document review or literature review and agency survey. Land use analysis uses image data from Google Earth digitization using the image interpretation method. This land-use data will be input data to be overlaid with the results of the tidal flood scenario. The data used in the analysis of tidal flood inundation scenarios start from the analysis of ground elevation values. The height data input uses DEMNAS data in 2011 which has a resolution of 0.24 Arc-second or around 8.2 meters [17]. The DEM data was then carried out to update the altitude due to the data entered using the 2011 database. There were changes in elevation such as elevation of roads and certain areas and even embankment construction in several locations.

Next, an analysis of tidal values with tidal input data obtained from the Meteorological, Climatological, and Geophysical Agency/ Badan Meteorologi, Klimatologi dan Geofisika (BMKG) of Tanjungmas Station in Semarang City during the period January-December 2019. The data was carried out smoothing because it was still in the form of raw data so that some noise needed to be removed. Finally, in the analysis of estimated waste generation, the data used are data from the sampling results of the scenario arranged into a $10 \mathrm{~m}^{2}$ grid which was originally $8.2 \mathrm{~m}^{2}$. The arrangement of the grid is done to facilitate the sampling of waste generation in the field and assumes that the homogeneity of data in one grid at a radius of 10 meters still has the same variation.

The analytical method used is a quantitative spatial approach. The spatial approach is used to construct the tidal flood scenario obtained from tidal values, SLR values, and land height values. Added SLR value because it is included in global warming which is assumed glaciers can melt so that the volume can increase [18]. Land height values are processed with the help of the ArcGIS application through raster grid data processing. The tidal analysis method uses the Admiralty method. This method is a calculation step to determine the value of HHWL (Highest High Water Level). HHWL values will be summed with SLR values that occur globally. The calculation formula is as follows.

Information :

$$
G=[(H H W L+S L R)-T]
$$

$\mathrm{G}=$ high flood inundation tidal flood

$\mathrm{T}=$ ground level

The results of the scenario will be tested by the model to determine the value of overall accuracy. The method used to calculate the Confusion Matrix method and then will also be calculated with the Kappa Coefficient index 
to obtain the degree of agreement [19]. The results of the inundation scenario that have been tested are then manually classified per $30 \mathrm{~cm}$. This value is determined by researchers to know more deeply the state of tidal floods with that height. Based on the results of the tidal flood scenario arranged in a grid format, then it will be sampled based on the height of the inundation in certain land uses. This sampling is determined by Proportionate Random Sampling and produces a total number of sampling grids that are 148 grids that are spread evenly over the tidal flood area. There are several steps that can be used to estimate waste including flooding such as (1) making a location map, (2) determining the amount of waste generation, (3) determining the area to be managed, and (3) compiling a topographic condition to model the height of a puddle $[13,20,21]$. The results of the tidal flood scenario grid have waste generation that does not cover fully. The measurement of waste generation can be measured by unit units such as per-m (road), per $\mathrm{m}^{2}$ (market, industry, and or certain areas that have length and width) [22]. Therefore, it is necessary to calculate the area of waste and then weigh the scattered waste in the grid as in the following explanation.

- The condition of waste generation spreads in the grid

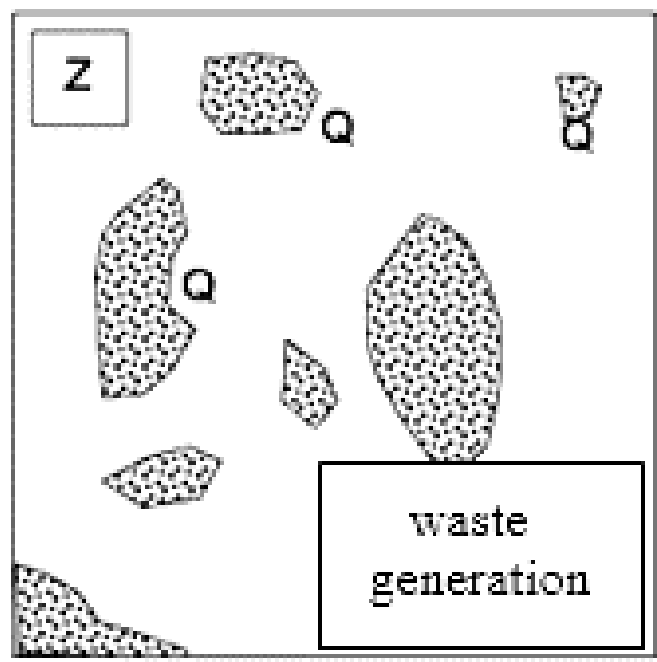

Fig. 2. The condition of waste generation spreads (Source: Analysis Results, 2019)

Formulation :

$$
Q Z=Q 1+Q 2+Q 3 \ldots+Q n
$$

- Waste generation conditions are evenly distributed but not fully covered in the grid

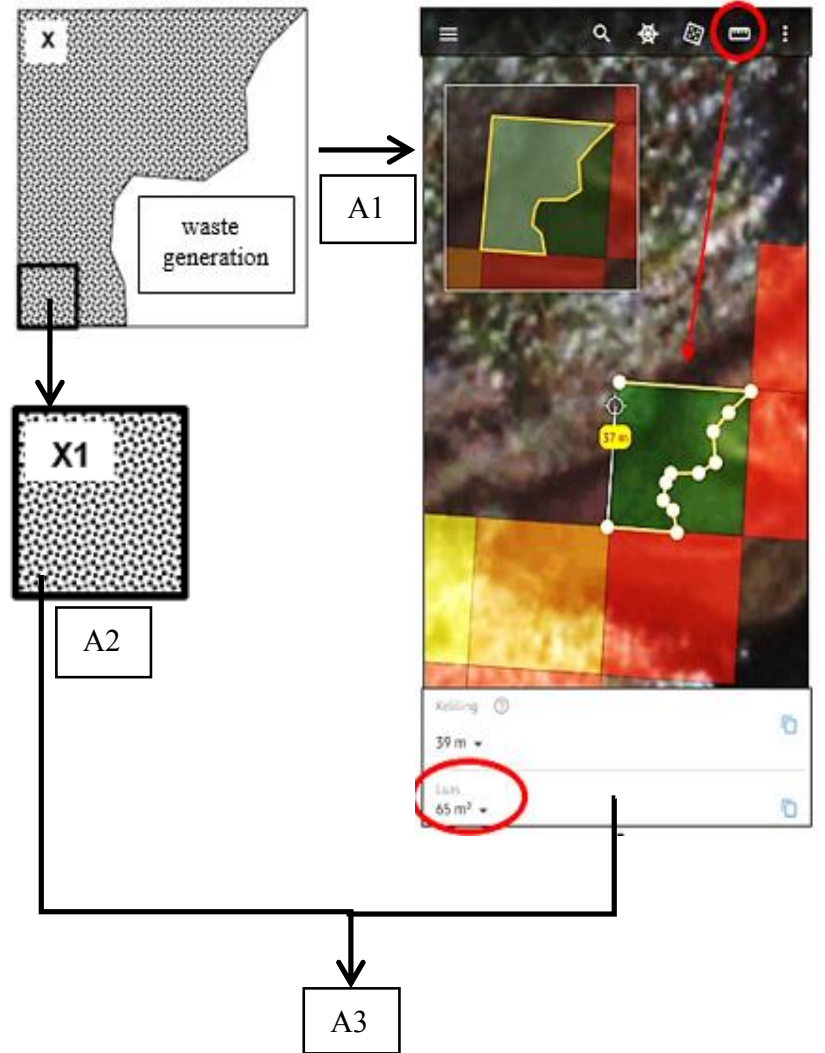

Fig. 3. Process estimation if condition of waste generation are evenly distributed but not fully covered in the grid (Source: Analysis Results, 2019)

Information :

A1 : area measurement of waste distribution with the Google Earth application on a smartphone

A2 : per-grid sample with a size of $1 \mathrm{~m}^{2}$ or $2 \mathrm{~m}^{2}$ at one corner A3 : calculation of waste generation

$$
Q \text { waste }=\frac{Q X 1(\mathrm{~kg})}{\text { Area } X 1\left(\mathrm{~m}^{2}\right)} \times \text { Area } X\left(\mathrm{~m}^{2}\right)
$$

\section{Results and discussion}

\subsection{Identification of land use}

In the northern part of the subdistrict, most of these are non-residential areas. The northern part of the Pantura Road is an area that is currently still vulnerable to tides. According to the Semarang City Regional Spatial Plan (RTRW) for 2011-2031, the northern part of the North Semarang Sub-District or the northern part of Pantura Road is designated as an industrial area, a port, a PLN substation, and a small part of the settlements in Tanjungmas and Bandarharjo Sub-Districts. 


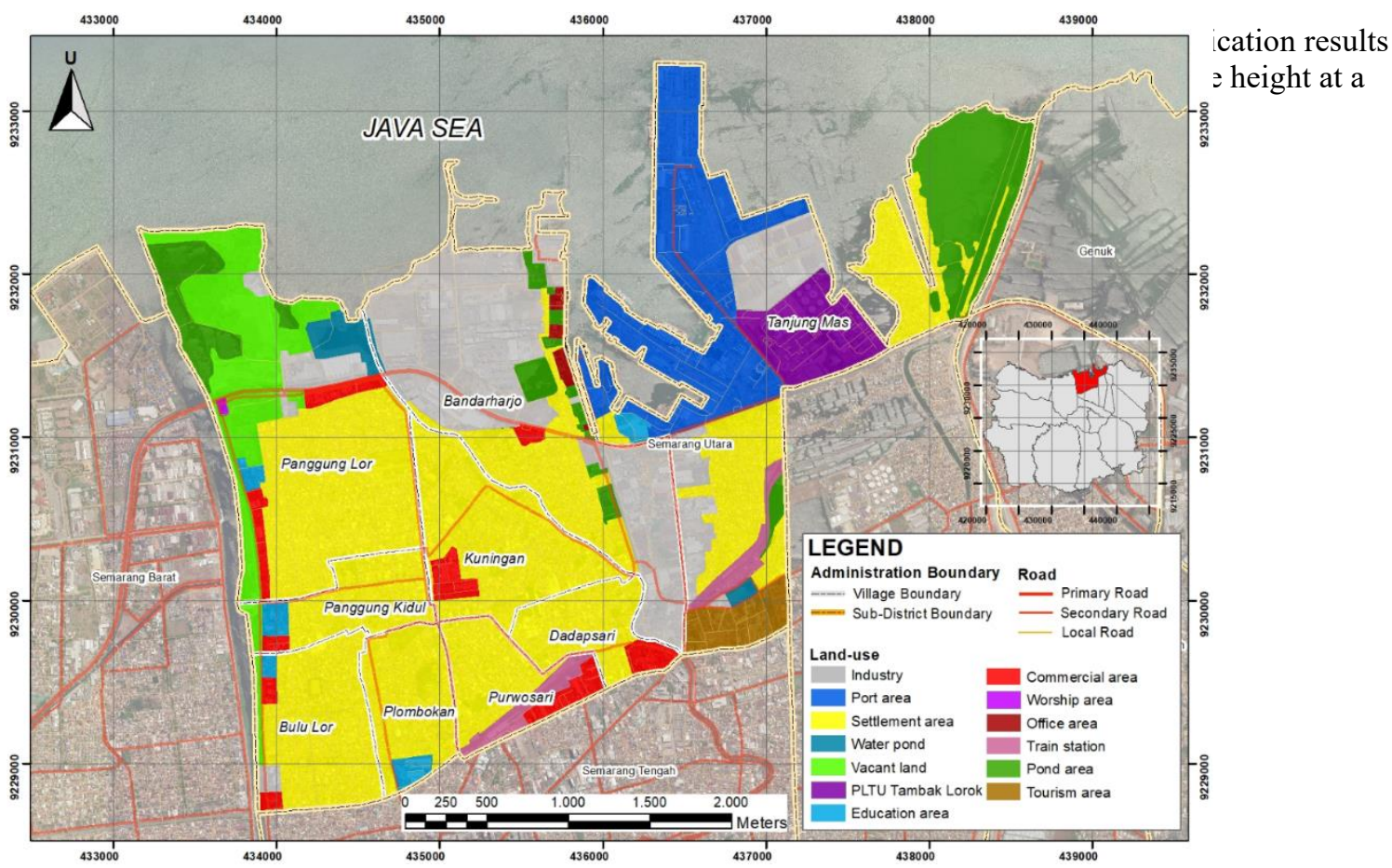

Fig. 4. Existing land use in North Semarang Sub-District (Source: Analysis Results, 2019)

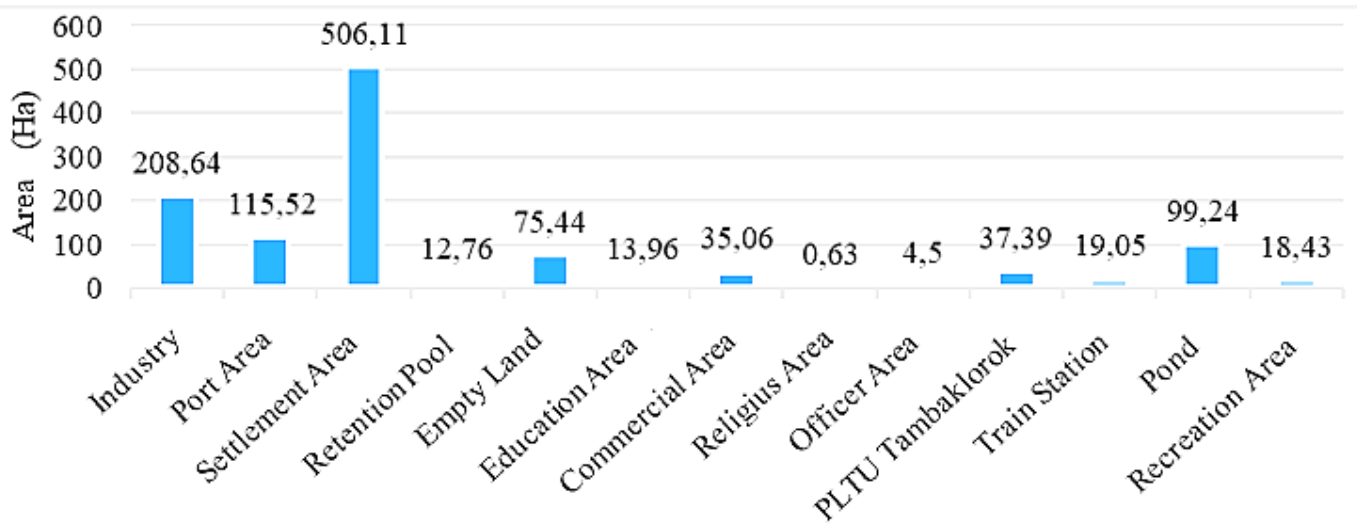

Fig. 5. Area of existing land use chart in North Semarang Sub-District

(Source: Analysis Results, 2019)

\subsection{Tidal flood scenario analysis}

\subsubsection{Analysis of Topography}

The results of processing ground elevation data through the National Digital Elevation Model (DEM) data or DEMNAS and land subsidence data obtained the classification of land elevation values. According to the mapping of the Semarang City Regional Planning and Development Agency, land subsidence is up to $10 \mathrm{~cm}$ per year [23]. In its adjustment, the 2011 DEM data was converted to 2019 DEM data by taking into account the land subsidence value of $0.8 \mathrm{~m}$. This data will be used as a parameter to measure the height of a tidal. The presentation of land height parameters is classified based on 10 classes.

Based on the results of land elevation classification in the figure above, all villages have elevations in the range certain point. This update was done because of the DEM data used in 2011, so it needs to be updated as an adjustment to the current situation. Measurements were made at certain locations where land elevations such as elevation of the harbor, riverbanks, roads, and several other areas such as industrial areas.

Renewal of DEM is carried out in the northern part of the northern coastline because this area is often affected by tidal flood and some areas are elevated. Grid preparation is done using the help of the ArcGIS application. The use of the Create Fishnet toolbar is needed to create points with a length and width of 10 meters. Cropping points are made to select points that are in the study area. The data point does not have a high value, so it requires high data input by matching the height data from the updated DEM using the Extract Multi Values to Point tool. Area with elevations less than the 
same as 1.5 meters widest are in Tanjungmas, Panggung Lor and Bandarharjo Sub-districts, which are $189.86 \mathrm{~m}$ respectively; $149.7 \mathrm{~m}$; and $77.69 \mathrm{~m}$. From this area, it can be concluded that the height of $0-1.5 \mathrm{~m}$ has a percentage of $48.41 \%$, while more than $1.5 \mathrm{~m}$ has a percentage of $51.59 \%$.
S2). The calculation result of Formzahl value is based on tidal data which is 1.10 , meaning that the type of mixed tide tends to double daily (mixed tide, prevailing semidiurnal), which is between $0.26<\mathrm{F}<1.50$. According to the classification, this type of tide is a classification of

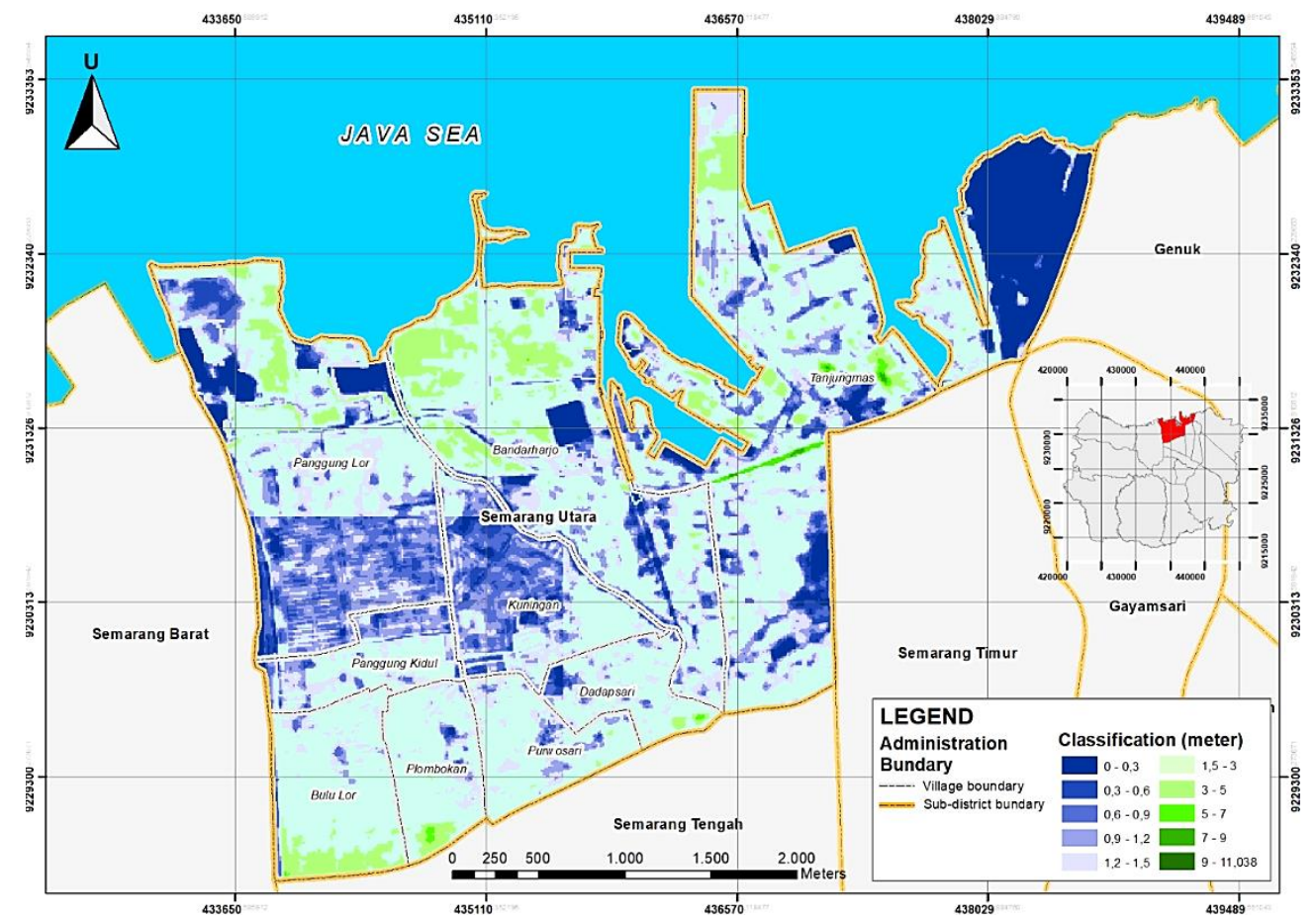

Fig. 6. Map of land height in North Semarang Sub-District (Source: Analysis Results, 2019)

\subsubsection{Tidal value analysis}

The tidal value of the coastal waters of the North Semarang Sub-District is processed using 2019 data from the Semarang Maritime BMKG. Tidal data is then smoothed to eliminate noise so that data with normal values can be obtained and can be done for further analysis.

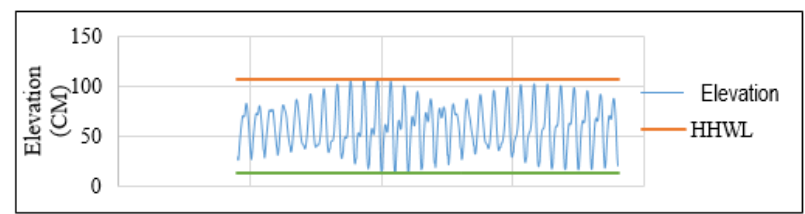

Fig. 7. Tidal sample graph on January in North Semarang SubDistrict 2019

(Source: Analysis Results, 2019)

This tidal data becomes the basis for the analysis of the highest and lowest tide values as well as knowing the type of tides in the Coastal North Semarang Sub-District. This tidal analysis is based on the Admiralty method. Calculation analysis using the Admiralty method shows that the Formzahl (F) value in the waters of the North Semarang Sub-District and surrounding areas. Formzahl number value $(F)$ is the value used to determine the type of tides. This value is obtained from the division between the amplitude of the main daily tidal constant (K1, O1) and the amplitude of the main double tidal constant (M2,

tides that occur two times and two times of ups and downs in a day but it is not certain and can occur one time and ups and downs with different heights and times.

Other tidal components from calculations using the Admiralty method are harmonic components. Harmonic components are tidal numbers which are used as a basis for calculating the highest seawater level (HHWL) and the lowest seawater level (LLWL) as well as the average value of water level or Mean Sea Level (MSL). The calculated components include S0, M2, S2, N2, K1, O1, M4, MS4, K2, and P1.

Table 1. HHWL in North Semarang Sub-District 2019

\begin{tabular}{|l|c|}
\hline Periode & HHWL (cm) \\
\hline January & 119,85 \\
\hline February & 111,26 \\
\hline March & 110,13 \\
\hline April & 110,65 \\
\hline Mey & 117,79 \\
\hline June & 122,08 \\
\hline July & 121,61 \\
\hline August & 117,69 \\
\hline September & 110,61 \\
\hline October & 112,07 \\
\hline November & 119,20 \\
\hline December & 123,55 \\
\hline Average & $\mathbf{1 1 6 , 3 7}$ \\
\hline \multicolumn{2}{|c|}{ Source: Analysis Results, 2019) } \\
\hline
\end{tabular}




\subsubsection{Analysis of tidal flood inundation scenarios}

The height of tidal flood inundation scenarios is obtained with HHWL, SLR, and land height data. The HHWL value obtained every month is then accumulated to get the highest tidal data per year. SLR values were obtained based on literature studies which reached $14 \mathrm{~mm}$ per year [5]. The results of tidal flood inundation scenarios are classified into 5 classes according to inundation height in certain land uses. This was also used in previous studies by the associated puddle of tidal flood in Pekalongan coast [8]. The method used in the division of this pool class is the Manual Interval on the ArcGIS application. This method is determined based on the accumulated value of HHWL and SLR which shows the highest tide height value of seawater reaching 1.27 meters. This value is classified in the range of $0.3 \mathrm{~m}$ from the first to the fifth class. But in the fifth or final class is a residual value.

Table 2. Calculation of tidal flood height in North Semarang Sub-District 2019

\begin{tabular}{|c|c|c|}
\hline HHWL+SLR & Ground Level & $\begin{array}{c}\text { Height of Tidal } \\
\text { Flood }\end{array}$ \\
\hline [A] & {$[\mathrm{B}]$} & {$[\mathrm{A}]-[\mathrm{B}]$} \\
\hline \multicolumn{3}{|c|}{ (meter) } \\
\hline \multirow{5}{*}{1,27} & $0-0,30$ & $0,97-1,27$ \\
\cline { 2 - 3 } & $0,30-0,60$ & $0,67-0,97$ \\
\cline { 2 - 3 } & $0,60-0,90$ & $0,37-0,67$ \\
\cline { 2 - 3 } & $0,90-1,2$ & $0,07-0,37$ \\
\cline { 2 - 3 } & $1,2-1,27$ & $0-0,07$ \\
\cline { 2 - 3 } & $\geq 1,27$ & 0 \\
\hline
\end{tabular}

(Source: Analysis Results, 2019)

The table shows that the height of the water level at the highest tide, when accumulated with SLR values globally, reaches 1.27 meters. The height of the land that has been classified with a range of $30 \mathrm{~cm}$ is the basic value to determine the height of inundation in the land. The difference in height of tidal flood on land will be the same, that is, $30 \mathrm{~cm}$, except in the last class, which is $7 \mathrm{~cm}$, because it is nart of the remaining calculation level.

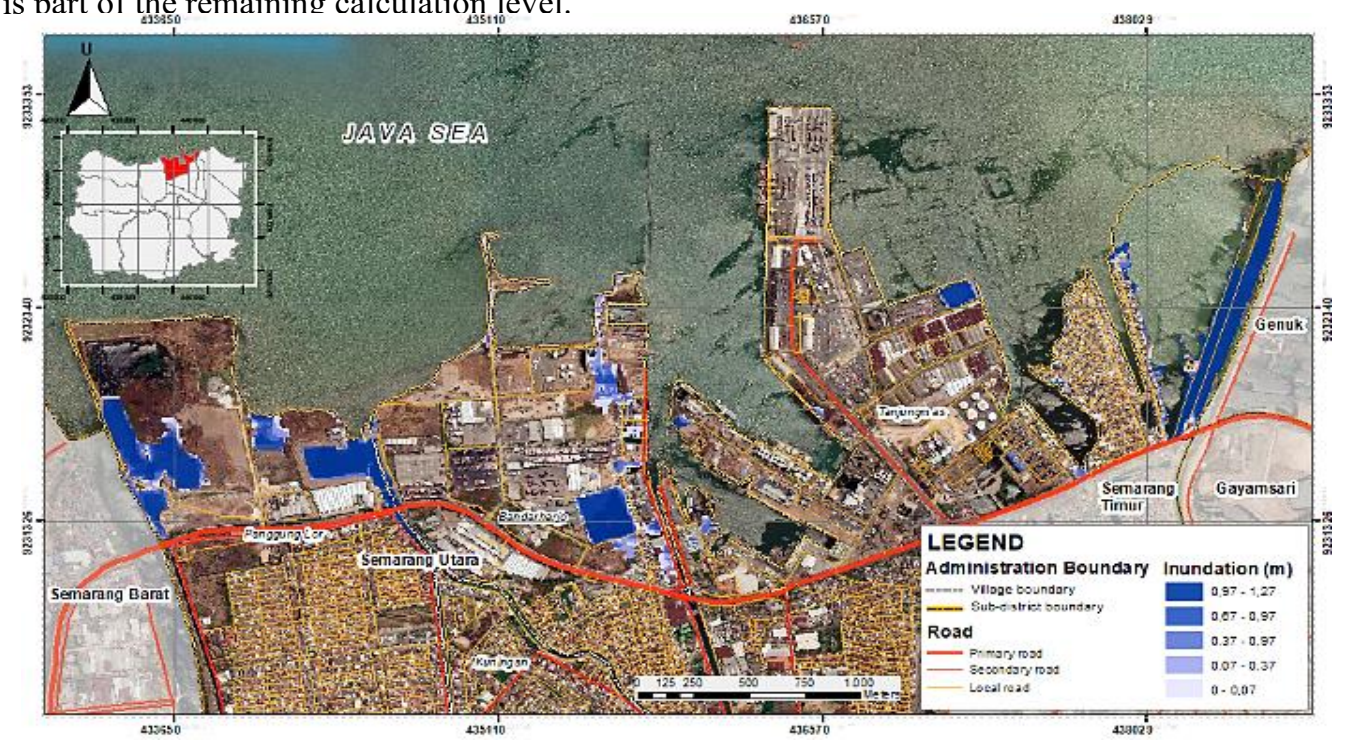

Fig. 7. Map of Tidal Flood Height in North Semarang Sub-District (Source: Analysis Results, 2019)
Table 3. Area of tidal flood height per-village affected

\begin{tabular}{|l|c|}
\hline \multicolumn{1}{|c|}{ Village } & Area (Ha) \\
\hline Bandarharjo & 14,28 \\
\hline Panggung Lor & 22,02 \\
\hline Tanjungmas & 19,65 \\
\hline Total & $\mathbf{5 5 . 9 5}$ \\
\hline
\end{tabular}

(Source: Analysis Results, 2019)

The state of tidal floods on certain land uses can have an impact such as waste with varying quantities. Dirty and moist conditions potencially become a potential of disease. Polluted waters due to the waste generation that was inundated with tides or tides. The tidal flood that inundated the North Semarang Sub-district certainly affected physical damage such as the erosion of road access.
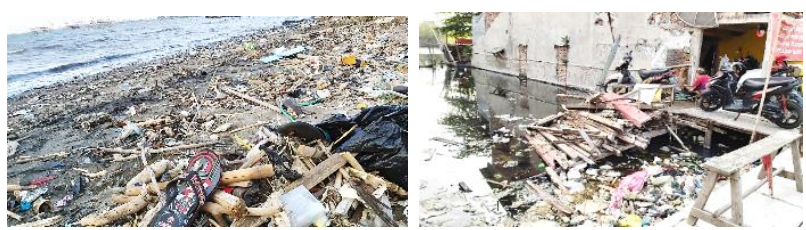

Fig. 8. Impact of tidal flood in North Semarang Sub-District (Source: Analysis Results, 2019)

The results of the tidal flood inundation scenario model are areas that are inundated or not inundated. The model will be tested based on field observations to show the suitability of the model with existing conditions. Field observations are made by marking points of spatial location that have coordinates using GPS. The results of field checking are then calculated for accuracy using the Confusion Matrix method that will be obtained Overall Accuracy results for the tidal flood model.

The calculation of the level of accuracy of the tidal flood inundation model which has a value of $82.86 \%$. Kappa Coefficient is also used in this calculation to 
determine the degree of agreement from the data. Based on the results of the Kappa Coefficient calculation, a range of 0.65 results is obtained, which means that it falls into the $0.6-0.8$ category, which is substantial, meaning that the results of the tidal flood model are sufficiently high and decent substantially.

\subsection{Estimation of waste generation based on scenario}

Estimation of waste generation due to tidal is determined based on the scenario model by taking the grid as a random and proportional random sample. Samples were taken on each grid inundation height on certain land uses as an area of tidal impact. A grid $10 \mathrm{~m}^{2}$ can be counted spatially over the entire scope of the tidal flood affected area based on the scenario. Grids are classified based on strata level of inundation depth in certain land uses. The sample is determined using the Proportionate Stratified Random Sampling method. The error rate used is $8 \%$ of the total population of the grid contained waste based on observation (visualization). The total number of grids is 5,595 grids, but the number is based on an analysis of land use affected by tidal flood and field observations affected by waste generation are only 2,260 grids. The minimum number of samples that can represent field data is 148 grids. area is then resampled based on a certain size. Next multiplied by the total area of waste spread in the grid. Illustrative illustration of waste sampling can be found in the data and methodology section.

The condition of the waste taken from the sample is waste caused by tidal flood both waste that is carried by the tidal flood to the land and waste in land that is inundated due to tidal flood. Waste generation due to tidal water is relatively wet so that it can increase the weight of the waste. The estimated quantity of waste generation is determined from the sampling of each tidal height scenario in particular land use. Waste consists of various types such as plastic, cardboard, rubber, and cloth. Based on observations in the field, in general, most tidal flood waste is a plastic waste. The results of these calculations are then carried out calculations for the entire grid on each height class in certain land uses. The calculation formula is as follows:

\section{Total sampling grid \\ Total grid \\ $\overline{\text { Quantity of waste generation on sampling grid }}=\overline{\text { Quantity of waste generation on gric }}$}

The table above shows that the estimated amount of waste generation due to tidal flood based on the scenario reaches around $70,095.25 \mathrm{~kg}$. Grid I with the highest tidal height is estimated to generate waste generation reaching

Table 4. Estimation of waste generation from tidal flood based on scenario

\begin{tabular}{|c|c|c|c|c|c|}
\hline Grid & Landuse & $\begin{array}{l}\text { Sampling } \\
\text { Grid }\end{array}$ & $\begin{array}{c}\text { Total estimation } \\
\text { of waste based } \\
\text { on sampling (kg) }\end{array}$ & $\begin{array}{l}\text { Grid } \\
\text { Total }\end{array}$ & $\begin{array}{c}\text { Total } \\
\text { estimation of } \\
\text { waste } \\
(\mathrm{kg}) \\
\end{array}$ \\
\hline \multirow{4}{*}{$\begin{array}{c}\text { Grid I } \\
(0,97-1,27)\end{array}$} & Industry/ Port area & 8 & 265,82 & 144 & $4.784,76$ \\
\hline & Settlement area & 4 & 109,69 & 76 & $2.084,11$ \\
\hline & Coastal area & 14 & 1573,91 & 250 & $28.105,54$ \\
\hline & Pond area (A) & 27 & 539,26 & 482 & $9.626,79$ \\
\hline \multicolumn{2}{|r|}{ Total Grid I } & 53 & $2.488,68$ & 952 & $44.601,20$ \\
\hline \multirow{2}{*}{$\begin{array}{c}\text { Grid II } \\
(0,67-0,97) \\
\end{array}$} & Coastal area & 5 & 365,65 & 85 & $6.216,05$ \\
\hline & Pond area (A) & 9 & 115,90 & 159 & $2.047,567$ \\
\hline \multicolumn{2}{|r|}{ Total Grid II } & 14 & 481,55 & 244 & $8.263,62$ \\
\hline \multirow{4}{*}{$\begin{array}{c}\text { Grid III } \\
(0,37-0,67)\end{array}$} & Industry/ Port area & 4 & 48,78 & 68 & 829,26 \\
\hline & Settlement area & 4 & 71,49 & 67 & $1.197,458$ \\
\hline & Coastal area & 5 & 241,27 & 98 & $4.728,892$ \\
\hline & Pond area (A) & 9 & 93,35 & 162 & $1.680,3$ \\
\hline \multicolumn{2}{|r|}{ Total Grid III } & 22 & 454,89 & 395 & $8.435,91$ \\
\hline \multirow{4}{*}{$\begin{array}{c}\text { Gird IV } \\
(0,07-0,37)\end{array}$} & Industry/ Port area & 4 & 9,46 & 79 & 186,835 \\
\hline & Settlement area & 5 & 53,89 & 90 & 970,02 \\
\hline & Coastal area & 6 & 169,33 & 103 & $2.906,832$ \\
\hline & Pond area (A) & 10 & 74,55 & 185 & $1.379,175$ \\
\hline \multicolumn{2}{|r|}{ Total Grid IV } & 25 & 307,23 & 457 & $5.442,86$ \\
\hline \multirow{4}{*}{$\begin{array}{c}\text { Grid V } \\
(0-0,07)\end{array}$} & Industry/ Port area & 5 & 8,77 & 84 & 147,336 \\
\hline & Settlement area & 7 & 35,75 & 129 & 658,8214 \\
\hline & Coastal area & 9 & 122,82 & 159 & $2.169,82$ \\
\hline & Pond area (A) & 13 & 20,35 & 240 & 375,6923 \\
\hline \multicolumn{2}{|r|}{ Total Grid V } & 34 & 187,69 & 612 & $3.351,67$ \\
\hline \multicolumn{2}{|r|}{ Total } & 148 & $3.920,04$ & 2.660 & $70.095,26$ \\
\hline
\end{tabular}

(Source: Analysis Results, 2019)

Measurement of waste generation area is measured for a waste generation that is spread evenly or not evenly distributed in the grid or only a portion of the grid area. Measured waste generation also has to accumulated characteristics. If the waste spreads, then a full measurement is carried out in one grid. The waste disposal
$44,601.20 \mathrm{~kg}$ or around $63 \%$ of the overall tidal height. Whereas the lowest tidal height is estimated to have generated waste at $3,351.67 \mathrm{~kg}$ or about $5 \%$ of the total tidal height. This estimation is based on the tidal flood scenario model which is divided into several levels of height strata classes on certain land uses. The 
characteristics of waste due to tidal flood have wet conditions because most are submerged in standing water so that it will add to the quantity of weight. This study of waste generation data will be useful in the planning and determination of the waste management system including equipment and financing. In the Disaster Waste Management Guidelines Guidelines for Asia and the Pacific by the Ministry of the Environment Japan, waste management due to disaster needs to be considered for reasons of risk including economic matters (resource efficiency or financial effectiveness). Recording waste generation data if not provided, management planning costs of management will be ineffective and inefficient. Waste generation data can also be basic data in planning the $3 \mathrm{R}$ management, namely efforts to reduce (reuse), reuse (reuse) and or recycle waste (recycle). The presence of waste also makes problems in the sanitation system and can endanger the aquatic ecosystem environment and pollute the water. Water conditions that become turbid and cause air pollution because they cause unpleasant odors. Through this study, it is conducted as a basic data on waste management due to tidal so that environmental health will be created.

\section{Conslusion and recomendation}

The results of the discussion that have been explained in the research related to "Estimation of Waste Generation from Tidal Flood in North Semarang Sub-District", produce conclusions or essence of the study.

1. Height of the high tide during the year 2019 which caused the phenomenon of tidal floods in the North Semarang Sub-District has an estimated height of around \pm 1,240 meters. Maximum inundation height occurs in June and December, which have a height of 1,221 meters and 1,235 meters, respectively.

2. Tidal flood scenario generated based on the maximum average tidal sea level in 2019 results in several villages affected by tidal floods in North Semarang Sub-District, namely Panggung Lor, Bandarharjo, and Tanjungmas. The largest village affected by tidal floods in the Panggung Lor Village with an area of $22.02 \mathrm{Ha}$. While Tanjungmas Village has a tidal flood area reaching $19.65 \mathrm{Ha}$ and Bandarharjo Village reaching an area of $14.28 \mathrm{Ha}$. Tidal floods occur as a result of land heights that are less than the maximum tide height. The component of sea-level height during high tides is also influenced by the Sea Level Rise (SLR) value, which is the value of increasing seawater volume due to the phenomenon of global warming.

3. Tidal flood scenario model in North Semarang SubDistrict has been tested using the Confusion Matrix method with field observation data and produces an accuracy value of $82.86 \%$. From the Confusion Matrix test results, calculations are also performed to produce a Kappa Coefficient and a value of 0.64 is obtained which means it is included in the Substantial category so that the data is feasible to use.

4. Estimation of waste generation due to tidal flood based on scenario models according to the height of certain land uses reaches 70,095.25 kg. This estimation is determined based on field sampling of several $10 \mathrm{~m}^{2}$ sized tidal flood affected area grids using Proportional Stratified Random Sampling. Inundation heights on grids 1 to 5 have consecutive estimates of waste that are $44,601.20 ; 8263.62$; $8,435.91 ; 5,442.86$; and $3,351.67 \mathrm{~kg}$. The data is a mixture of waste that has relative types of plastic, wood, rubber, and fabric waste. Such waste can harm the environment including water and air pollution and cause poor environmental visualization.

The waste generation data is the basis for planning waste management in the area affected by tidal flood, including financing and technical waste collection. Through estimation of waste generation due to tidal data, the role of government and / or authorities is needed for good environmental planning through effective and efficient waste management due to tidal waste. For this reason, there are several activities the government can do.

1. Planning for the management of the clean up of tidal waste generation including costs and equipment as a form of increasing awareness of disaster waste management.

2. Increasing the provision of solid waste facilities including the procurement of the location of the Integrated Waste Collection Site around the tidal flood area.

3. The technical planning of waste collection because the collection of waste due to tidal flood will be different from the collection of environmental waste in general.

The research is funded by Directorate General of Research and Development, Ministry of Research, Technology and Higher Education through Institute of Research and Community Services Diponegoro University Fiscal year 2019 with Number 101-147/UN7.P4.3/PP/2019.

\section{References}

1. C. Bellard, C. Leclerc, F. Courchamp, Potential Impact of Sea Level Rise on French Islands Worldwide, J. Nat. Conserv., 5, pp. 75-86, (2013).

2. H. S. Hansen, Modelling the Future Coastal Zone Urban Development as Implied by The IPCC SRES and Assessing The Impact from Sea Level Rise, J. Landsc. Urban Plan., 98, no. 3, pp. 141-149, (2010).

3. I. Buchori, A. Pramitasari, A. Sugiri, M. Maryono, Y. Basuki, A. W. Sejati, Adaptation to Coastal Flooding and Inundation: Mitigations and Migration Pattern in Semarang City, Indonesia, J. Ocean Coast. Manag., 163, pp. 445-455, (2018).

4. G. McGranahan, D. Balk, B. Anderson, The Rising Tide: Assessing The Risks of Climate Change and Human Settlements in Low Elevation Coastal Zones, J. Environ. Urban., 19, no. 1, pp. 17-37, (2007).

5. I. Buchori, A. Sugiri, M. Mussadun, D. Wadley, Y. Liu, A. Pramitasari, I. T. D. Pamungkas., $A$ Predictive Model to Assess Spatial Planning in Addressing Hydro-Meteorological Hazards: A Case 
Study of Semarang City, Indonesia, Int. J. Disaster Risk Reduct., 27, pp. 415-426, (2018).

6. B. T. Widyantoro, Karakteristik Pasang Surut Laut di Indonesia, J. Ilm. Geomatika, 20, no. 1, pp. 6572, (2015).

7. Fadilah, Suripin, P. S. Dwi, Menentukan Tipe Pasang Surut dan Muka Air Rencana Perairan Laut Kabupaten Bengkulu Tengah Menggunakan Metode Admiralty, J. Maspari., vol. 6 (1), pp. 1-12, (2014).

8. I. A. Cahyaningtias, Model Spasial dan Temporal Genangan Banjir Rob Menggunakan Sistem Informasi Geografis: Studi Kasus di Pesisir Pekalongan, Departement of Marine Science, Brawijaya University, (2018).

9. Maryono, Evaluation of Disaster Resilience on Waste Management in Developing Countries, Disertasi Doktor, Departement of Urban and Enviromental Engineering, Khusyu University, (2015)

10. F. He, J. Zhuang, Balancing Pre-Disaster Preparedness and Post-Disaster Relief, Eur. J. Oper. Res., 252, no. 1, pp. 246-256, (2016).

11. Y. Wakabayashi, T. Peii, T. Tabata, T. Saeki, Life Cycle Assessment and Life Cycle Costs for PreDisaster Waste Management Systems, J. Waste Manag., 68, pp. 688-700, (2017).

12. T. Tabata, H. Morita, A. Onishi, "What is The Quantity of Consumer Goods Stocked in a Japanese Household? Estimating Potential Disaster Waste Generation During Floods', J. Resour. Conserv. Recycl., vol. 133, pp. 86-98, (2018).

13. H. Nakayama, T. Shimaoka, K. Omine, Maryono, P. Patsaraporn, O. Siriratpiriya, 'Solid Waste Management in Bangkok at 2011 Thailand Floods', J. Disaster Res., vol. 3, no. 3, pp. 356-346, (2013).

14. T. Sutari, Sampah Muara Angke Mencapai 50 Ton, CNN Indonesia, 2018. [Online]. Available: https://www.cnnindonesia.com/nasional/20180319 130722-20-284139/sampah-muara-angkemencapai-50-ton (Accessed : May 16, 2019.).

15. UN-OCHA, Disaster Waste Management Guidelines, Edition 2, Switzerland: Joint UNEP/OCHA Environment Unit (2013).

16. Maryono, H. Nakayama, T. Shimaoka, Identification of Factors Affecting Stakeholders, Intentions to Promote Preparedness in Disaster Waste Management: A Structural Equation Modeling Approach, J. Mem. Fac. Eng. Kyushu Univ., 74, no. 3, pp. 79-98, (2015).

17. Geospasial Informayion Agency, DEMNAS: Seamless Digital Elevation Model (DEM) dan Batimetri Nasional, 2011. [Online]. Available: http://tides.big.go.id/DEMNAS/ (Accessed: February 19, 2019).

18. H. Latief, M. R. Putri, F. Hanifah, I. N. Afifah, M. Fadli, D., Ismoyo, Coastal Hazard Assessment in Northern Part of Jakarta, J. Procedia Eng., 212, pp. 1279-1286, (2018).
19. J. R. Landis, G. G. Koch, The Measurement of Observer Agreement for Categorical Data, Biometrics, 33, no. 1, pp. 159-174, (1977).

20. R. Albano, A. Sole, J. Adamowski, L. Mancusi, $A$ GIS-based Model to Estimate Flood Consequences and The Degree of Accessibility and Operability of Strategic Emergency Response Structures in Urban Areas, Nat. Hazards Earth Syst. Sci., 14, no. 11, pp. 2847-2865, (2014).

21. T. Tabata, Y. Wakabayashi, P. Tsai, T. Saeki, Environmental and Economic Evaluation of PreDisaster Plans for Disaster Waste Management: Case Study of Minami-Ise, Japan, J. Waste Manag., 61, pp. 386-396, (2017).

22. N. E. Wahyuningsih, T. Joko, P. N. Prabamurti, Buku Ajar Persampahan. Semarang: UPT Undip Press, (2014).

23. Bappeda Kota Semarang, RTRW Kota Semarang 2011-2031. 